\title{
Labour migration from east to west in the context of European Union integration
}

\begin{abstract}
The enlargement of the European Union (EU) has increased the importance of the issue of migration. The discussion up to now has been focused mainly on migration from central and eastern European countries to western European ones; much less attention has been given to the impact of migration on the economic development of sending countries as well as immigration in them. This paper aims to contribute to a more balanced view of migration regarding both sides of the debate. The article analyses labour migration from and in central and eastern European countries over the last twenty years and discusses the participation and integration of such migrants in the EU labour market. The main hypothesis of the article is that the differentiated labour inflows of immigrants in the two EU regions (western and eastern EU member countries) could have asymmetric impacts on the quality of the labour force (human capital) as well as on economic development, depending on the extent of the substitution and complementarity effects among groups of natives and foreign-born workers.
\end{abstract}

Keywords: migration, central and eastern Europe, European Union, labour market

\section{Introduction}

After the political changes in central and eastern Europe ${ }^{1}$ (in 1989), a large wave of emigrants from these countries fled to western Europe as well as some other countries. $^{2}$

Under the conditions of the latest EU enlargement (with central and eastern Europe - ten countries on 1 May 2004 and two others on 1 January 2007), the free mobility of labour has transformed into a kind of internal mobility of the labour force. The liberalisation of the EU labour market and the growing demands for the economic and political integration of central and eastern European countries into the EU have brought migration to the top of the policy agenda. This is recognised in almost all the documents of the European Commission but a satisfactory, legitimate solution has thus far not been found.

1 In this paper they are also called new member countries or new EU member countries.

2 We consider labour emigration in the broad sense of this concept, which means people who cross national borders legally or illegally and remain outside their countries of birth or citizenship for a longer period, generally for at least a year. We include people who can resettle or stay abroad who take a job, as well as students or other people staying there temporarily and being potentially employed in the host countries. Commuting is a special form of labour migration. 
Labour force mobility from central and eastern European to other countries within the EU changes national and regional labour markets. It has an impact in a different way on individual countries and societies depending on whether they are host or sending countries. The result is that some advantages, challenges and problems may be observed in the two types of countries.

The EU faces a great challenge: to turn the economy of this community into a very dynamic and competitive one based on the broad application of new technologies, the development of innovation and education, new jobs and social security. For the new member countries, these challenges are even greater.

The central and east European region has a specific status within the European migratory area due to its geographic location and economic situation. Statistics describing migrants of long-term and permanent residence show that, in the last decade, the countries of this region have gradually become an attractive target for immigration. This phenomenon leads to a greater diversity of migrants in the EU and, therefore, of its human capital. The flows of transit migrants heading 'further to the west' are routed through the territory of central and east Europe and, for this reason, it is often described as a buffer zone (with the countries themselves often being termed transit countries). Most of these countries are located on the new outer eastern EU border.

This article is focused on labour migration from and in central and eastern Europe. It aims to contribute to a more balanced view of the process of labour migration, regarding both sides of the debate. The main hypothesis is that differentiated labour inflows of immigrants in the two EU regions ('old' and 'new' EU member countries) could have asymmetric impacts on the quality of the labour force (i.e. human capital) quality and thereafter on economic development.

The paper is organised as follows. It starts by offering a short overview of population mobility from the new member countries ${ }^{3}$ to western European ones in the context of labour market developments in the enlarged EU. Subsequently, the economic impacts of migration relevant to the labour market are presented both as regards the host and the sending countries. It is recognised that migration produces a wide range of both positive and negative economic effects in the host and the sending countries. These issues are followed by a short overview of labour immigration in the new member states. The concluding part discusses the strategies and policies of European migrants related to the labour market.

\section{Population mobility from the 'new' to the 'old' EU countries}

The enlargement of the European Union (EU) increased the importance of the issue of migration, both as a process of the free movement of labour from the new member countries and as a fear within the EU-15 of 'massive migration from the east'. ${ }^{4}$

The new migration flows depend mainly on the level of economic development and the demographic situation both in the sending and the host countries. As a rule, the

3 These are as follows: Bulgaria; the Czech Republic; Estonia; Hungary; Latvia; Lithuania; Poland; Romania; Slovakia; and Slovenia.

4 It turned out, that after the 2004 and 2007 enlargement of the EU, the real number of migrants from central and eastern Europe in the EU-15 was much lower than the predicted number. 
level of demand in the labour market in the host countries is a very powerful pull factor; while poor living conditions and limited prospects for higher living standards in the countries of origin constitute the basic push factor for migration. ${ }^{5}$

The immigrant labour structure in EU-15 countries depends, on the one hand, on the shortage of labour in different labour markets; ${ }^{6}$ and, on the other, on the EU strategy for a knowledge-based economy and on the highly-skilled labour force which is necessary for this purpose but which is limited in number.

The intensity of migration can be illustrated by the data on net migration rates (Table 1). The data on net migration, derived from population statistics and available for most countries over relatively long periods of time, suggest that several countries have experienced strongly negative net migration rates over extended periods of time (i.e. the outflows dominate the inflows). During the early years of the transition to a market economy, the Baltic countries were typical of the most intensive migration (reflecting the return migration of ethnic groups). Bulgaria, Poland and Romania also experienced high negative net migration rates. The other countries, such as Hungary and the Czech Republic (and also Slovenia apart from the very beginning of the transition and Slovakia apart for the first few years of the new century), are ones where the average migration balance was positive. Bulgaria and Romania became important source countries well before their accession in 2007. In response to the large inflows after the first EU enlargement, Ireland and the United Kingdom chose to restrict access to their labour markets to people from Bulgaria and Romania in 2007. The most attractive destination countries then became Italy and Spain.

Table 1 - New member countries: net migration rates, 1992-2007 (\%)

\begin{tabular}{|l|c|c|c|c|}
\hline & $\mathbf{1 9 9 2 - 1 9 9 5}$ & $\mathbf{1 9 9 6 - 1 9 9 9}$ & $\mathbf{2 0 0 0 - 2 0 0 3}$ & $\mathbf{2 0 0 4 - 2 0 0 7}$ \\
\hline Estonia & -17.1 & -4.9 & 0.1 & 0.1 \\
\hline Latvia & -11.6 & -3.0 & -1.3 & -0.5 \\
\hline Lithuania & -6.5 & -6.1 & -2.1 & -2.1 \\
\hline Bulgaria & -2.7 & 0.0 & -6.5 & 0.0 \\
\hline Slovenia & -1.1 & 0.1 & 1.7 & 3.6 \\
\hline Romania & -0.9 & -0.5 & -6.1 & -0.3 \\
\hline
\end{tabular}

5 According to Eurostat data, nearly 27 million foreigners live currently within the EU area, which is less than $5 \%$ of the total number (i.e. of about half a billion people). Approximately 6.4 million foreigners live in Germany; 4 million in France; 2.7 million in the United Kingdom and in Spain; 2.6 million in Italy; and so on. Most foreigners come from non-European countries. The share of migrants in the different countries varies from $39 \%$ in Luxemburg to less than $1 \%$ in Slovakia, while the average share is between 2 and $6 \%$. It should be taken into account that the definition of migration is within the competence of individual EU countries and that Eurostat produces total data on the number of migrants as given by them.

6 The rapid increase of labour demand in western Europe, in particular after 1997, has provoked more intensive population mobility. 


\begin{tabular}{|l|c|c|c|c|}
\hline & $\mathbf{1 9 9 2 - 1 9 9 5}$ & $\mathbf{1 9 9 6 - 1 9 9 9}$ & $\mathbf{2 0 0 0 - 2 0 0 3}$ & $\mathbf{2 0 0 4 - 2 0 0 7}$ \\
\hline Poland & -0.4 & -0.3 & -3.0 & -0.5 \\
\hline Slovak Republic & 0.3 & 0.3 & -0.9 & 0.8 \\
\hline Czech Republic & 0.9 & 1.0 & 0.0 & 4.2 \\
\hline Hungary & 1.7 & 1.7 & 1.1 & 1.7 \\
\hline
\end{tabular}

Sources: Eurostat; and IMF staff calculations (see R. Bems and P. Schellekens, 2008).

De-population in western Europe resulted in steady immigration in the region. An ageing population and slow economic development also gave rise to increasing immigration there. The demographic trends in central and eastern Europe are akin to these, but even worse in comparison with those of western Europe. The data in Table 2 show that a natural decrease in the population is typical of all the new member countries except for Slovakia (but, even there, the increase is minimal; 0.2 per 1000 ). In the EU-25, the natural increase is also low (0.7), but the coefficient of net migration (3.7 per 1000 ) considerably offsets this figure. In none of the central and eastern European countries could similar indicators be detected. Judging by net migration, most of them turned into sending countries although some did become receiving countries. ${ }^{7}$ Net migration in Slovenia and the Czech Republic is much closer, but lower in comparison with the EU-25 (3.6 and 3.5 per 1000 respectively). The comparatively good positions in terms of net migration within the two countries are due mainly to the inflow of citizens from countries with which they formed one entity, i.e. before 1991 and 1993 respectively. The higher levels of mortality in the region also contribute to less favourable demographic developments compared with the EU-25; with the exception of Slovenia and Poland, mortality is higher everywhere in the region. The number of deaths per one thousand head of population is especially high in Bulgaria (14.6), Latvia (14.2) and Hungary (13.4). ${ }^{8}$ It is alarming that mortality is worsening, especially among men of working age. These developments have a deep impact not only on the age structure and the overall size of the labour force, but also on the employability of the older (or even younger) age groups.

7 For example, the proportion of Poles in the total number of migrants from central and eastern Europe in the EU is about $24 \%$; Romanians, $19 \%$; Bulgarians, $4 \%$; etc.

8 Mortality depends also on the age structure. The high mortality rate in Bulgaria is probably linked to the large outflow of mainly young people from the country which has occurred in the last couple of years. The result of this has been that the age composition of the country has deteriorated. 
Table 2 - EU-25 and the new member countries: demographic indicators per 1000 head of population (2005)

\begin{tabular}{|l|r|r|r|c|c|c|}
\hline Country & $\begin{array}{c}\text { Popula- } \\
\text { tion (000) }\end{array}$ & $\begin{array}{c}\text { Live } \\
\text { births }\end{array}$ & Deaths & $\begin{array}{c}\text { Natural } \\
\text { increase/ } \\
\text { decrease }\end{array}$ & $\begin{array}{c}\text { Net } \\
\text { migra- } \\
\text { tion }\end{array}$ & $\begin{array}{c}\text { Effective } \\
\text { increase/ } \\
\text { decrease }\end{array}$ \\
\hline EU-25* & 457216 & 10.5 & 9.7 & 0.7 & 3.7 & 4.4 \\
\hline & & & & & & \\
\hline Bulgaria & 7450 & 9.0 & 14.6 & -5.6 & -1.8 & -7.4 \\
\hline Czech Republic & 10241 & 10.0 & 10.5 & -0.5 & 3.5 & 3.0 \\
\hline Estonia & 1333 & 10.6 & 13.1 & -2.5 & -0.3 & -2.8 \\
\hline Hungary & 10007 & 9.7 & 13.4 & -3.8 & 1.7 & -2.1 \\
\hline Latvia & 2290 & 9.3 & 14.2 & -4.9 & -0.5 & -5.4 \\
\hline Lithuania & 3597 & 8.9 & 12.9 & -4.0 & -3.0 & -7.0 \\
\hline Poland & 38558 & 9.8 & 9.7 & -0.1 & -0.6 & -0.7 \\
\hline Slovakia & 5431 & 10.0 & 9.8 & 0.2 & 0.8 & 1.0 \\
\hline Slovenia & 2011 & 8.8 & 9.2 & -0.4 & 3.6 & 3.2 \\
\hline Romania & 22330 & 10.2 & 12.3 & -2.1 & -0.5 & -2.6 \\
\hline
\end{tabular}

* The current number of EU member countries (27) excluding Bulgaria and Romania.

Source: Eurostat, Chronos Database; data on population are taken from the A. Maddison series, see www.ggdc.net

Up to now, the new member countries of the EU have shown differentiated behaviour concerning labour market integration. The outflow of people from Slovenia, the Czech Republic, Hungary and (in part) Estonia has been rather modest, while Poland and the other two Baltic countries (Lithuania and Latvia) have revealed high migration trends. High levels of migration may be observed in Slovakia, mainly within its geographic proximity - Austria, Czech Republic and Hungary.

The likely number of Hungarians working in one of the EU countries is about 25-30 thousand. The estimated figures since joining the EU have increased to about 50 thousand. Most Hungarians work in Austria (22 000), while the second most preferred destination is Germany (12000) and then the UK (1 000). Up to several thousand people work in the other 'old' EU members (Fóti, 2007: 60). A recent survey carried out by the European Central Bank (2006) shows Germany as the most preferred country for citizens of the 'Višegrad Four', i.e. the Czech Republic, Slovakia, Poland and Hungary; $37 \%$ want to migrate here. The other preferred countries are Austria, 24.4\%; the UK, $6.4 \%$; France, $4.1 \%$; etc. whereas only $2.8 \%$ of them would choose another new member country. 
From the official data of the National Statistical Institute (NSI) in Bulgaria (which, in contrast to Hungary, is a net sending country), an average of 45000 people per year emigrated in the 1990s, most of them being young people which has aggravated the problem of an ageing population. From 1989 up to now, nearly one in ten Bulgarians has emigrated. The most attractive countries for permanent settlement are two - the USA and Germany. ${ }^{9}$

Migration from the xxyy is destined mainly to the countries of western and southern Europe: mainly Germany and the United Kingdom, but also Italy, Spain, Ireland and Belgium. The attractiveness of these countries mainly comes from conditions in their own labour markets and an insufficient labour supply in specified activities; a comparatively easy access to labour, both for legal and illegal foreigners; a labour policy which is favourable to foreigners; a higher price of labour in comparison with that applying in the country of origin; etc. ${ }^{10}$ Emigrants are included mainly in the service sector, construction and, albeit less likely, in industry. The shortage of labour in some southern countries (Italy, Greece, Spain and Portugal) opens the opportunity for mainly illegal employment in agriculture.

Another group of countries are the Scandinavian ones where migration is relatively less intensive. This is due to precisely the opposite conditions being found there: a restrictive migration policy, including successful measures against illegal migration; a low level of unemployment; a lack of, or otherwise hampered, access to the labour market or to opportunities to carve out a professional career; more difficult adaption to the demands of employers on the local labour market; etc. At the same time, Scandinavian countries are among the most developed. This experience, as well as that of many empirical studies, disproves the main hypothesis of the neo-classical theory of migration: it turns out that the differences in GDP per capita between countries is not a sufficient factor for migration and these differences alone could not explain this phenomenon.

9 According to the latest NSI forecast, migration from Bulgaria will gradually decrease and, after 2010 , the number of migrated people is expected to be 6-8 thousand annually. They will continue to be mainly young people. After 2020, it is expected that the number of immigrants in the country will exceed that of emigrants. Concerning migration trends in central and eastern Europe by group, younger and better-educated individuals are the ones more likely to move. Very well-paid workers are less likely to emigrate and, in contrast, the youngest and most educated emigrants are the least likely to return.

10 In the case of Bulgaria, even the price of the lowest-skilled illegally-taken job in a host country is higher than that of highly skilled work in the country of origin (except for some jobs in foreign-owned companies). 
Labour migrants abroad can be divided into three specific groups (Rangelova, 2006: 50-73):

a) Highly-educated migrants, including students ${ }^{11}$ may work abroad during their course of study and/or continue working after finishing it. All these people are connected with the so-called brain drain.

Many bright researchers and faculties do their best to move abroad and work at prestigious scientific centres or universities in developed countries in order to practise their profession in a more productive manner. There is empirical evidence that, for academic migrants from the new member countries, unemployment could not be considered as a 'push' factor for their inclination to emigrate

b) Legal labour migrants, both educated and uneducated. It is clear why this group is the largest in comparison with the other two: legal labour migrants are important because they have an effect on labour markets both in the host and in the origin countries, as well as because of the sharpened sensitivity in the former due to the active mobility of the population in central and eastern European countries (Rangelova and Vladimirova, 2005: 201-223)

c) Illegal migrants. The number of emigrants in this group is the smallest in comparison with the other two. These people carry out some labour activity in a drastically different way in comparison with the other two groups.

There are differences between the figures produced by well-known research institutes on migration, but there are at least three major issues which have been proved (Inotai, 2008: 156-157). Firstly, the anticipated number of migrants turned out to be much higher than the real number of immigrants after the 2004 and the 2007 enlargement of the EU. Secondly, during the first wave of enlargement, a much higher wave of migration from Bulgaria and Romania, not yet members in 2004, took place almost unnoticed. Even now, there may be more Romanians (between 2.5 and 3 million) working in the EU-27 than Poles. The figure for Bulgarian migrants, at nearly 800 000, is higher

11 According to Eurostat, the number of young people in the EU-27 who study in another European country is growing annually by approximately $5 \%$. Up to now, however, this growth has paralleled the general growth in the number of students, i.e. the percentage of internationals has remained relatively constant - at nearly $2 \%$ of the total number of students. Cypriot and Luxembourger students have been the most mobile, given the few local universities while over $10 \%$ of Maltese students have studied abroad in another European country. They are followed by Greek, Irish, Slovak and Bulgarian students, who are all significantly more mobile than the rest of their European peers $(6 \%$ to $8 \%)$. At the other end of the scale, i.e. those who are least inclined to study abroad, are Polish and British students. Similarly, Romanians are in no rush to study in European higher education schools. For example, the Romanian population is nearly three times as big, but the number of Bulgarian young people in a European university is larger than that of Romanians by about 4500 students. Moreover, when it comes to registered international students in Romanian universities, they number about 1500 such students less than the number in Bulgarian ones (Vass, 2007: 125-133).

It should be taken into account that the best students from central and eastern Europe migrate to western higher education schools without returning to their home country. However, no authority in a new member country takes any interest in what happens to students who have left their country to study abroad and in what happens to those who hold undergraduate or graduate degrees from prestigious universities. 
than that of other new EU member countries in comparison to the total working population. Thirdly, the fundamental 'migration threat' to the enlarged EU comes not from the east but from the south, particularly from northern and sub-Saharan Africa.

Labour supply does not generate demand on the labour market in 'old' EU countries; immigrant employment is concentrated in some sectors of activity such as construction, hotels, restaurants, trade, agriculture, etc. ${ }^{12}$

\section{Economic effects of immigrants on the host EU country's labour market}

There are a large number of theoretical studies on the long-run consequences of immigration for host countries. It is recognised that, in the short-term, immigration usually has negative consequences - a rise in unemployment, wage pressure on markets with flexible pay, more use of welfare provision - but, in the medium- and long-term, the influx of new labour contributes to economic growth. From the perspective of the neoclassical growth model, international migration is a positive mechanism that accelerates convergence in income per capita and wages, thereby producing equilibrium flows among capital-abundant receiving countries and capital-scarce sending ones.

The proponents of migration note the positive economic role that immigrants can play, for instance in terms of addressing specific labour shortages and the problems linked to ageing populations. Opponents of migration, on the other hand, fear adverse impacts on the labour market, on public finances, on social conditions and on the distribution of income.

Some of the EU-15 countries have long traditions in immigration. In general, immigrants have a positive impact on the adaptation of the labour market and in realising economic growth. Italy, Portugal, Spain, Greece and Ireland, known in the past as typical sending countries, have gradually turned into receiving countries.

Economic migrants are usually motivated and mobile, so their entry into the western European labour market may help to moderate the excessive growth of labour costs and thus maintain international competitiveness. Immigration may also boost demand for goods and services and help to moderate excess demand for labour in specific sectors or regions.

Among other economic effects on host countries, immigration is generally seen as an exogenous change in the labour supply for fixed capital stock as immigrants are normally considered to be endowed with little physical capital. From such a perspective, a standard supply and demand model would predict wage decreases and employment losses. Western European public opinion is generally hostile to further migration on account of high and persistent unemployment and widespread fears that economic growth will no longer lead to increased employment. Various studies, however, reveal that immigrants' damping effects on wage growth are much smaller than is commonly supposed and affect only limited sectors of the economy.

12 There are available data on the labour realisation of Bulgarians in Greece and Spain, which countries are similar in terms of labour supply for immigrants, mainly in the service sector (Markova, E (2004) 'Legal Status and Migrant Economic Performance. The Case of Bulgarians in Spain and Greece' paper presented at the conference To Be A European. Bulgaria and Europe in Europe: Past, Present and Future University College London, 5 March 2004). 
Despite there being no obvious relationship between immigration and unemployment, concerns are often expressed that immigration will lead to higher unemployment and lower wages for the native population. These concerns are especially evident in many European countries, where unemployment rates are higher and the proportion of long-term unemployment is greater than in many non-EU OECD countries. In theory, the labour market impact of immigration depends on how immigrants' skills compare with those of nationals in the host country.

In general, the presence of immigrants in the EU labour market could be considered from different perspectives: firstly, it is a favourable factor for cultural diversity; secondly, in the near future it will lead to stronger competition in the struggle for jobs between local people and foreigners; thirdly, it could also be a factor in the intensification of economic progress by means of opening new jobs both to foreigners and to local people. ${ }^{13}$

In many publications we can find arguments that the increasing inflow of a lowpaid labour force from central and eastern European to western countries will decrease wages in host countries, in particular in some professional labour markets. Eurostat data for the three countries which did not undertake migration restrictions after 1 May 2004 - Ireland, the UK and Sweden - show that non-closure of labour markets had a positive influence on their economic growth. This experience has stimulated other western European countries to act in a similar way.

Typical of migrants from the former socialist countries is the relatively high proportion of women. Over the previous decades, they had been encouraged both to educate themselves and to participate actively in paid work and set out a professional career. In this way, they obtained economic independence, skills and the will to get on the labour market. The observed increase in the employment rate in western Europe over the last decades is accompanied by the so-called externalisation of housework (domestic staff, cleaning staff, care for old people and children). This means more and more employed people, in particular women, preferring to hire others to do domestic work for them. There are two basic groups of people related to this purpose: nativeborn low-income people; or women who have emigrated from central and east European countries. The latter, as usual, are educated but their diplomas are not valid in western Europe.

In general, labour force mobility from central and eastern Europe to other countries within the EU changes national and regional labour markets there. Immigration in cen-

13 International migration has long been a concern in both originating and receiving countries. At the beginning of this decade, the debate was focused on the role that immigration may play in easing the economic and budgetary impacts of the declining and ageing OECD populations. The impacts of immigration concerned five themes linked to migration in OECD countries: (a) What are the consequences of immigration for labour market performance? (b) What role can immigration play in easing skilled labour shortages in specific sectors? (c) What are the budgetary impacts of immigration? (d) To what extent is immigration a solution to ageing and declining OECD populations? and (e) What are the consequences of migration for economic development in the source country? (see J. Coppel, J-C. Dumont and I. Visco, 2001). On these issues, see also: G. J. Borjas (1993); F. Daveri and R. Faini (1999); United Nations (2000); etc. 
tral and east European countries, which is mainly from non-EU countries, also contributes to the changes in the labour market in Europe. Labour force mobility has different impacts on individual countries and societies. Modern labour markets could be analysed in the following way: emigration from a given country means immigration in another country (or countries). The disadvantages coming from large-scale emigration and the 'brain drain' from sending countries should lead (and they really do) to advantages in the receiving countries.

\section{Migration and its consequences for the sending country's labour market}

The discussion so far has been focused mainly on migration from central and east European countries to western European ones and on the impact of migration on potential host countries. Much less, if any, attention has been given to the impact of migration on socio-economic development and prospects in the sending countries. This article tries to realise a more balanced view of migration regarding both sides of labour migration.

It is recognised that emigration produces a wide range of economic effects in sending countries, both positive and negative.

Depending on the initial situation and the internal flexibility of the national labour markets of sending countries, the results of migration can be very different. In addition, differences in short-term and longer-term prospects have to be taken into account. The most positive short-term impact is on the decrease of unemployment. In the 1990s, migration from central and eastern Europe mitigated the severe social problems caused by the high unemployment rate and the pressure on the national labour markets. This was particularly important for countries with high unemployment rates: Poland; Slovakia; Romania; and Bulgaria. In this case, the budgetary impacts are positive because fewer unemployment benefits must be paid. ${ }^{14}$

The disadvantages for the country of origin of the emigration of its skilled labour force are obvious. A skilled but low-paid labour force coming from the new member countries to 'old' Europe is very valuable for many employers there. Central and east European countries, however, worry because many of the best specialists are leaving their own countries looking for higher payment and better living standards. The migration of medical doctors and other medical specialists from central and eastern Europe, in particular from Romania, Poland, Bulgaria and Hungary, has been increasing over the last years. Health reforms and the problems of health care systems in central and eastern European countries make medical specialists choose rather to leave than to stay in the country of origin. There is a large number of vacancies in the health care sector in west European countries. Due to administrative barriers or other circumstan-

14 A substantial proportion of low-skilled workers from the under-developed regions of a country who used to commute within the framework of a national labour market have seized the opportunity to look for a job in other European countries. 
ces, however, these specialists often take jobs which do not match their qualifications. ${ }^{15}$

High hopes are connected to the transfer of technology inspired by migrants. In reality, however, the technology-related 'brain drain' is much more sizable than the 'brain gain'. Countries with large-scale emigration are increasingly facing labour shortages in high-tech areas, with negative implications for foreign direct investment in general and technology transfer in particular. ${ }^{16}$

The large-scale emigration of mainly young and, in labour terms, active people has led to a declining labour force in central and east European countries. There have been examples that the decreasing labour available to agriculture has resulted in technological changes in production via the initiation of investments in the mechanisation of this sector. Such gains can, however, easily be converted into losses if a large number of migrants happens to emerge from among the young, relatively well-educated and mobile parts of the population which have stable or improving employment prospects at home. The problem may be aggravated if the internal mobility of labour is low and surplus labour in one region or sector is not ready to flow to other regions or sectors. In addition, if a large part of the mobile population from a depressed region leaves the country, intra-country regional differences are likely to widen and catch-up chances will be reduced (or at least substantially delayed).

The outflow of people from a country leads to a reduction of tax revenues which reflects negatively on the state of the pensions and health funds in the country.

The sending country loses part or all of its long-term investment in human resourcebuilding. Young and skilled people have benefited from taxpayer money during the many years of education in their native country. If, however, they migrate abroad, the social return from such investment is reduced and taxpayers are, in fact, subsidising human capital and productivity growth in the host countries. Obviously, the greater the 'brain drain', the lower the return in the new member countries on their public investment in higher education. In turn, this investment will generate additional growth in the new target country but not at home. There is widespread evidence, however, that a large number of young post-university (or generally post-education) migrants accept jobs that have nothing to do with their previous education. The result is that previous investments will be either substantially downgraded or completely lost.

15 According to a national survey within the UK (2007), nearly $47 \%$ of all migrants from central and eastern Europe with higher education or some professional skills have taken jobs for lowskilled people: domestic staff; cleaning staff; caring for old people and children; hotel staff; etc. In contrast, official data in Bulgaria show that, over the first eight months of 2008, 1230 nurses left the country, mainly on account of the low salaries (about $€ 150$ per month). Nearly 830 of them have legalised their education certificates and 400 have not - which means that the latter do not intent at all to practise their profession. At the same time, the health care sector in Bulgaria badly needs medical staff.

16 Theoretically, given that any 'brain gain' can only be exploited if the native country is able to create an attractive environment (absorption capacity). But, even in this case, the balance of costs and benefits is generally negative to sending countries, particularly in the first stages of migration. 
Throughout the current decade, high economic growth has led to the emergence of labour force shortages in some of the new member countries. Several sectors are facing serious labour shortages, such as agriculture, retail trade, personal and social service activities and, not least, the construction sector. The situation in the latter is particularly contradictory since part of what remittances are made are expected to flow into the construction industry and the housing market. In general, to increase the labour supply there are several basic approaches, such as attracting immigrants into the country and/ or by increasing the pay of local workers, thus keeping them in the country, or by attracting migrants to return. In this context, labour shortages have become rapidly accompanied by higher wages mostly, but not exclusively, in shortage sectors since wage increases have a 'demonstration effect' and, with some delay, they also reach the wage levels and structures of other sectors which do not have serious labour shortage. ${ }^{17}$

The additional negative of rapid wage increases (generally decoupled from productivity increases) can be observed in terms of growing inflationary pressures, as observed in the Baltic countries, Bulgaria, Romania and Poland. This may seriously hinder the implementation of national convergence plans aimed at fulfilling the conditions for introducing the Euro.

Migration generally has different impacts on selected regions of a given country. Unemployment-driven migration affects disproportionately those regions which have high levels of unemployment, while 'brain drain'-related migration is concentrated in more developed parts of the country (based around universities). In addition, first-wave patterns of migration may generate second-wave migration from the same region based on family and relative networks.

The current world financial crisis, followed by the reductions in economic activity, has brought an expected reaction amongst migrants - to come back or, at least, to transfer more money (savings) to their country of origin. Due to the increased unemployment in host countries, many migrants at least think about the option to return (even temporarily) to the country of origin.

Considering the intra-country impacts of migration, it should be noted that migration from desperate rural areas to urban centres in some European countries has contributed to de-population and a backwardness of the abandoned regions. Such a process is fully contrary to the cohesion policy of the EU financed by substantial transfers from the common budget.

Immigrant labour structures in 'old' EU countries depend, on the one hand, on the shortage of labour supply in different labour markets and, on the other, on the EU strategy for a knowledge-based economy, demanding a highly-skilled labour force. The new EU member countries have similar (even more severe) demographic problems but they can not compete with 'old' EU countries in attracting the necessary immigrant

17 In 2007 alone, wages in the construction industry grew by $20 \%$ in Poland, $25 \%$ in Romania and $35 \%$ in Latvia. Polish companies struggling to attract labour to their activities in or around Warsaw had to increase not only salaries (to about $€ 700 \mathrm{a}$ month) but offer free-of-charge transport or even accommodation - but without success (Inotai, 2008: 162). 
labour force. Thus, the serious problems concerning the competitiveness and productivity of their economies grow deeper.

Migrant remittances are the most frequently discussed positive consequence for sending countries. These come mainly from labour migrants (both long-term and shortterm) and less from settlers who have invested in houses, cars or the education of their children in the host country. Money transfers tend to grow over time. These transfers ensure living and additional income for family and relatives in the country of origin. ${ }^{18}$ In a national context, this is a way to increase the volume of foreign currency coming into the country of origin, while such money helps the state balance of payments. ${ }^{19}$ Money remitted is a significant factor in economic growth as far as it is used for higher consumption and investment. Such funds also help the development of regions from where migrants have gone abroad.

Taking into account the much lower level of income in new member countries, it is evident that money transfers are spent mainly on consumption. Due to limited domestic production, they are spent mainly on imported goods. In this way, we can account for unforeseen levels of increases in consumption. It turns out that the 'export' of people from central and eastern Europe enables governments to report (thanks to the remittances) successful economic development. Furthermore, increased consumption theoretically entails an inflationary pressure which means it could make the local currency more expensive. In this sense, we can speak of the marginal impact of remittances on economic growth in the sending countries.

Migration is likely to affect different sectors of the economy differently, which could generate some imbalances. At present, particularly strained situations have emerged in some sending countries in such sectors as agriculture, the construction industry, health care, university education or selected hi-tech sectors, with very different skill and education requirements.

If the most talented scientists and entrepreneurs leave for abroad, host countries will come to own more patents and will take advantage of this. For the country of origin, this means a likely reduction in the proportion of good jobs in the restructured economy. Due to the absence of highly-skilled specialists in the home country, economic activity will need to adjust more or less to the available human capital.

In obtaining higher skills and wider contacts abroad, emigrants can contribute to the expected positive changes in the economic and social life of their own countries. In many cases, migrants, in particular highly-skilled professionals, develop a successful career abroad and obtain international experience. They have learned cultural lessons and thus they are able to transfer the professional and managerial skills and experience they gained while abroad (Rangelova and Vladimirova, 2005). Such people confront

18 In general, migrants send more money to their relatives during economic crisis in the country of origin.

19 According to the Agency for Bulgarians Abroad since 2003 at least 300 thousand emigrants have been transferring to their families small amounts ranging from USD 100 to USD 300 monthly. These amounts could be treated as social assistance coming from remittances instead of from the state budget. The amount of money sent by migrants to Bulgaria is increasing from year to year. 
in close detail the problems of international integration, social cohesion and a modern lifestyle.

Migrants from the new member countries could become more effective for their countries of origin: coming back and, having sufficient financial means, migrants could start their own business. The last statement is particularly important in the context of the general assumption that, if risk-taking people are more inclined to migrate, returning migrants should also be more risk-taking than the average in the population. However, risk-taking supported by some amount of money has two important 'regulatory' aspects. The first is the age of the returnees. The later they return, the higher the likelihood that their basic behaviour will not be directed towards business ventures but towards the quiet life. This second aspect is connected with the given economic and sociopolitical environment in the country of origin. The higher the unpredictability and nontransparency of the latter, the lower the level of risk-taking activities.

Migrants' network-building promises a number of advantages. It focuses on sharing the success of migrants with native people. Migrants in developed countries may be able to generate additional trade and investment flows, encourage tourism and improve the financial stability of the home country. Diasporas can successfully contribute to the positive image-building of their home country. In many cases, diasporas can also have a certain bargaining power in shaping relations between their host and native countries in political, cultural and economic terms.

In a long-term perspective, however, central and east European countries will need to cope with a combination of two factors: de-population and an ageing population like in developed western European countries but in the conditions of low-income economies. As far as migrants are mainly young, educated and ambitious people, the demographic crisis has been deepened and this leads to negative effects on the quantity and quality of human capital.

Such an exodus of brains can be explained. On the one hand, gifted young people abroad find themselves in an environment that guarantees high-quality education and internationally-recognised degrees. On the other hand, such students may be offered good financial incentives and, for the most competent among them, the opportunity to advance their career within universities, research institutes or large-scale multinational companies. It goes without saying that the receiving country draws great benefits from capitalising on these foreign talents. If they do not return to their home countries, such countries lose added value potential that could help their economic development.

As a rule, migrants are more adventurous and ready to take risks than are people living in the country of origin. The absence of active and highly-skilled people from the sending countries limits the chances for creating and developing businesses there. In the case of central and east European countries, this has happened simultaneously with the very important period of political, economic and social transformation and the requirement for marked progress to be made.

Some people left behind in the country of origin are, as a consequence, de-motivated to put into practice a creative economic and social attitude to national progress. In many 
cases, they are tempted by the successful examples of their peers, demonstrating that the only right route to personal success is migration. ${ }^{20}$

There is no doubt that working abroad may have widespread positive impacts on the medium- and longer-term development of the sending country. However, the size of this influence, as well as its time horizon, is far from being predictable: both factors are predetermined to a great extent by the migration policy implemented both in the sending country and abroad.

\section{Labour immigration in the new EU member states}

Labour immigration in three central and eastern European countries is briefly discussed below: two of them - Hungary and the Czech Republic - are host countries regarding net migration; while Bulgaria is a sending country.

The age structure of immigrants in Hungary is favourable from the point of view of economic activity because most of them are young and of an active age in labour terms (25-49 years). Immigration has been especially visible since 1997 . Regarding the structure of immigrants from the point of view of the country of origin, it can be assumed that income and wage differences, as well as a common language, traditions and culture have played the most important role. Around $40 \%$ of all immigrants come from Romania, where the largest Hungarian minority lives (about 1.5 million people), and the wage differences are considerable. There is also a number of immigrants from Ukraine, which is also a country of origin for many ethnic Hungarians (Fóti, 2007: 49-66).

The Czech Republic attracts different groups of incoming migrants according to the push-pull theory, in which the key factors include job demand, favourable economic opportunities, political freedoms and cultural and linguistic proximity in the host country, etc. The largest proportion of economically active migrants are men of active labour age. The majority of the holders of job permits are from the former Soviet republics, in particular Ukraine. Current migration into the Czech Republic has a predominantly economic character. Roughly $70 \%$ of all officially-registered foreigners in the Czech Republic are economically active. Their real numbers are probably much higher because official statistics do not include foreigners who work in the informal economy and holders of permanent residence permits.

The experience of Bulgaria is particularly interesting because of its specificity as a typical south-eastern country located at the heart of the Balkans. The country is an EU member, in contrast to neighbouring countries which are pursuing the same aim. Bulgaria provides an outer border for the EU which means that, in many cases, it is treated by immigrants as a transfer country. In a broader sense, economic migrants come from different geographical regions and countries: Russia; Ukraine; the Arab world; China;

20 Studies in Bulgaria refer to practice in villages in the Rhodope Mountains, from which many adults have migrated to Spain and send money regularly to their children in Bulgaria. The latter are known in the terminology on migration as 'remittance people'. They are not motivated to look for jobs or to organise a business, relying only on the money sent by their parents or other relatives. 
neighbouring countries; and others. Labour immigrants enter mainly from lower-developed countries.

There are essential differences between emigrants from and immigrants in Bulgaria on the basis of educational level, professional skills and participation in economic activity.

According to the data of the Employment Agency in Bulgaria, the number of foreigners coming from non-EU countries and taking jobs is continually increasing, markedly so after the country entered the European Union. Immigration in Bulgaria differs from immigration in developed western European countries on the basis of the following features (Rangelova, 2008: 133-152): ${ }^{21}$

- immigrants in western European countries are treated as 'periphery' workers, marginalised from the economic centres of their society, as well as people who have to take jobs that the local people do not want. Immigrants in Bulgaria are regarded as people who can be hired but who can also hire employees

- there are almost no immigrants hired by Bulgarians, but there are quite a few Bulgarians hired by immigrants. That means that immigrants create jobs rather than take them away from Bulgarians

- immigration in Bulgaria began later and is relatively smaller in number than immigration in developed western countries

- migrant inflows in Bulgaria are incomparably smaller in number than those of migrant outflows from the country

- immigrants have not been desperate and extremely poor people in their countries of origin. Neither are they impoverished people in Bulgaria (excluding refugees)

- for many of them, Bulgaria is not the terminal but a transfer country in their intention to move to western Europe

- there are two basic groups of labour immigrants playing a comparatively more important role than others in the Bulgarian labour market: the first comes from the near and middle East; and the second comes from China. There are some differences between these two ethnic groups of immigrants: ${ }^{22}$

- the employment structure of Arab immigrants by activity is as follows: in the retail trade - nearly $47 \%$; in the service sector - about $28 \%$; in wholesale trade - over $20 \%$; and in production activity - only $4.3 \%$. Highly-educated immigrants are not willing to agree to the very low pay in Bulgaria and prefer to develop their own businesses. In the vast majority of cases, Chinese people are low educated and are engaged in two economic sectors: restaurants; and trade (wholesale and retail). Arabs are the main competitors of Chinese people in the two economic sectors. More aggressive Chinese people succeeded in ousting Arabs from some of their easily conquered positions earlier - at the beginning

21 Immigration from non-EU and non-European countries to western European countries has a long tradition and is an important factor in the labour market and economic development of the EU, but this issue is outside the scope of this article.

22 The specificity of the two groups of people was revealed by a survey carried out at the beginning of the current decade (see Anna Krasteva (Ed.) Immigration in Bulgaria, 2005 International Centre for Minority Studies and Intercultural Relations: Sofia. 
of the 1990s. Some Arab immigrants came for the first time to Bulgaria in the last two decades, while the rest were already studying there in universities in the 1970 s and 1980s

- immigrants from Syria, Iraq and the Lebanon are typified by easier and better levels of adaption compared with other nationality groups of immigrants. This could be explained by them being the biggest and the oldest migrant colonies in the country

- Arab migrants are predominantly men. Women are less in number and do not carry out paid work. Most women do not speak the local language, making their integration into the local population more difficult. Chinese women are as active and as 'visible' as their husbands (partners)

- in terms of economic activity, immigrants could be regarded as 'representative' of their countries of origin. In the host countries, they are even more enterprising and more ready to take risks. Together with the positive side of this feature, we can mention the observed practice of smuggling, in particular among Chinese people.

The new EU countries face even more severe demographic problems than those in 'old' Europe but the result of the serious problems of productivity and the competitiveness of their economies is that they can not compete with the latter in attracting the necessary immigrant labour force. Given the large-scale migration of specialists and other educated and skilled people from central and eastern Europe to western Europe, who often take jobs which do not match their qualifications, it could be claimed that this is a loss mainly for the sending countries which have invested in these people as regards their education but not used them on the labour market. However, this is also a waste for the whole EU economy.

Owing to the still-limited number of immigrants in central and eastern Europe, ${ }^{23}$ their presence on the labour market has not yet created problems but, in the light of their increase in number, it is possible to envisage complications in the future.

Notwithstanding the favourable age structure of immigrants in central and east European countries, it is difficult to demonstrate that immigration has, so far, had any meaningful impact on the demographic situation. If the possible demographic impacts of migration are considered, it is clear that the current patterns and trends do not lend support to any significant effects, not only because their total number is comparatively small but also because the fertility pattern of most migrants is similar to that of the native population.

\section{Labour migration policies in the EU}

The opening up of the labour market of the EU-15 to new members in 2004 and 2007 constituted one of the toughest chapters in the negotiations process for accession. Based on justified or unjustified fears, and as a result of different national labour market policies as well as the priorities of public opinion, the EU-15 introduced a seven-year transition period for the complete opening of the enlarged market for one of the four freedoms of the single market (the free circulation - or mobility - of labour). The United

23 The share of the foreign-born population in several western European countries amounts to $10 \%$ or higher, but the same indicator hardly exceeds $1 \%$ in most new EU member countries. 
Kingdom, Sweden and Ireland immediately eliminated previous obstacles to the free flow of labour, while other countries followed suit in 2006-2007. At present, only Austria and Germany, and to some extent France, have serious barriers.

The new EU member countries applied the same labour market policy as their EU-15 counterparts: they opened up their labour markets to citizens of those countries that behaved in the same way with their citizens; and kept them closed, or under control, with those who applied the same rules. In 2007, most new member countries abolished any kind of restriction on the inflow of Bulgarian and Romanian labour, while only two EU-15 members (Finland and Sweden) followed the same practice. Hungary, which opened up its labour market only partially, was the sole exception (in 2007 in 219 different activity areas; and in 2008 in all areas but only for skilled workers). The United Kingdom, which had played a pioneering role in 2004, started to introduce some restrictions on potential migrants from the two new member countries in 2007. Bulgaria disregarded the reciprocity principle and did not introduce any barriers to labour coming from other EU member countries.

Central and eastern European countries face another serious challenge: how could they develop competitive economies, improving for this purpose their human capital. This means that, in conjunction with other efforts, they need to take measures to mitigate migration from their own countries. In order to be able to compete with other EU countries, new member countries have to achieve higher economic development based on human intellectual potential.

Population mobility within the EU is a subject of labour market policy. Labour force mobility and the consequences that follow are predetermined by the level of education systems, the competitive level of individuals, differences in living standards and living conditions, etc. Migration systems present some similarities across countries, but institutional arrangements vary widely and do have an impact on the size and composition of migration flows (Box 1). 


\section{Box 1. Immigration labour policies in selected European countries}

Austria accepts immigrants based on yearly fixed quotas as a percentage of the labour force in the country. The required number of immigrants is estimated by the Austrian Institute for Economic Studies. So-called important workers are able to obtain a permit to work in the country on the basis of different quotas. This is the mechanism to attract highly-qualified employees. In order to obtain a permanent permit for work, a given immigrant should have at least five years legal residence in Austria and should have applied firstly for a labour licence and, after that, receive an individual work permit. This procedure shows that the Austrian system is very complicated, operating on the basis of considerable administrative discretion, which implies why it has not been able to attract enough immigrants, including highly-skilled ones.

The system in Portugal is similar to that in Austria. The decision to admit immigrants into the country are taken by the administration and are based on estimates of labour market need. According to these estimates, a yearly quotas for immigrants is defined. In reality, however, the real number of immigrants engaged in the grey economy is more than double this as they come mainly from the ex-colonies of Portugal and from eastern Europe.

The immigration policy in Cyprus is different. It follows the logic of temporary residence for labour immigrants. After finishing the term of the permit, any immigrant should leave the country. There is no system in Cyprus which gives permanent work permits and actual settlement of the immigrant in the country. The result is that most immigrants in Cyprus are low-skilled people looking for seasonal and not highly-paid work.

The immigration labour policy in Ireland is based on the economic demands of the country, depending on the deficit in the labour force and on the skills possessed by immigrants. A basic feature of this policy is that it is based on labour market signals but not on the estimates and discretion of the administration. This makes the system very flexible and effective. There are no limitations on people from other EU countries or from countries in the European economic space settling and working in Ireland. The basic demand of immigrants from countries outside the European economic space is a work permit. The system of work permits is based on the number of vacancies which employers could not fill with people from the European economic space. To prove the need to employ foreigners, any employer should declare the position at the National Employment Agency and, if there are no local candidates for these jobs within the next month, they could be filled by immigrants. Work permits are given to employers for preliminary defined workers or to employees for a fixed term.

The immigration policy system in Bulgaria is similar to that of Ireland. There is a limitation on a given employer, which may employ foreigners up to $10 \%$ of the total number of staff. There is also a requirement for a particular immigrant applying for a job to have passed the socalled 'market test', i.e. the job could not be taken by a local person. At present, immigration policy concerning the labour market in Bulgaria is in a very dynamic process of adaptation to the new economic situation - the level of economic progress attained and membership of the EU. Recently, the 'market test' was lifted for foreigners of Bulgarian origin. Until recently, the unemployment rate in Bulgaria was high but it has decreased and is now near the average for EU countries $(7.75 \%$ in 2007$)$. The main economic problem which remains is the very low pay, which does not stimulate foreigners to work in the country.

Source: http://ec.europa.eu

Most European countries have developed different polices, plans and programmes for attracting migrant workers and for their successful inclusion in the labour market, corresponding to the European Strategy for Labour Migrants. Many of these countries apply different numerical quotas or incentives to attract the labour market migrants who are desired and to restrict the less desirable ones. As of today, there is no comprehensive initiative.

National policies in developed countries towards immigrants are predetermined first of all by the needs of the domestic labour market. A crucial point in this policy is 
to facilitate the migration of highly-skilled specialists in the field of new technologies and health care. Low-skilled migrants, or those without good professional experience, could be taken for a period only if they are needed for the economy. This policy is aimed at attracting young and educated specialists from the new EU countries due to the low pay and currently unsatisfactory conditions for establishing professional careers which exist there. Business in some of these countries is not yet well organised to invest sufficiently in the labour force. This leads to further negative consequences for the countries of origin in terms of productivity and the competitiveness of their economies.

The result of large-scale emigration from some new member countries has been that contradictory effects have already become widely felt. In the last decade, most of the governments of these countries have started to evaluate the current situation and shape longer-term strategies for migration. Some basic elements of these strategies are as follows:

- despite a mixed experience, all new members countries continue to emphasise the importance of the free circulation of labour in the enlarged $\mathrm{EU}^{24}$

- some countries like Poland, Bulgaria and Romania, with experience of large-scale migration to western Europe, are now interested in attracting labour from their even less-developed neighbours such as Moldova, Ukraine, FYR Macedonia, or even Turkey and Russia

- some half-hearted initiatives have been taken in order to keep mainly highly-skilled people and workers employed in shortage areas at home. Such efforts can, however, barely work efficiently since the most important regulator remains the market and the wage gap between the domestic and the potential target country remains very significant

- active government policies must focus more on immigration in order to substitute for native emigrants. Efforts have been undertaken to seek the return of some migrants, in particular the young, the skilled and risk-taking people, from abroad. However, in designing such instruments, policy-makers have to bear in mind that special privileges are generally not able to compensate for an average socio-economic environment and a lack of business confidence.

In order to avoid, or decrease, the risk of the best students from new member countries migrating to western higher education schools and not returning to their home country, these countries should:

a) facilitate the access of students from central and eastern European countries to foreign higher education institutes

b) capitalise on the foreign university education of students from new member countries upon their return home.

New member countries confront important challenges in terms of migrants' economic effectiveness: firstly, they invest in the education and training of people who, later on, leave the countries; and, secondly, they have to invest in immigrants to ensure a higher level of professional and language training, re-skilling, etc. At the national level, this

24 Full liberalisation is scheduled in 2011 for the new member countries that joined in 2004 and by 2014 for Bulgaria and Romania. Future members must calculate on similar, or even stricter, international regulations. 
means a double investment. Due to the continuing unfavourable demographic processes in central and eastern Europe as regards the labour market, including large-scale emigration on the one hand and the increase of their economies on the other, labour force shortages may be observed. This is why the new member countries have to study what role immigration can play in filling the labour shortages caused by emigration. What is 'the price' of the 'substitution' of people from the new member countries by foreigners?

As regards migration, the present and future policy of the EU will lead to significant direct and indirect effects on a number of parameters of economic development, both in host and sending countries. At a superficial level, this concerns the problems of internal regional migration and labour markets.

It is understandable that host countries are interested in a selective migration policy attuned to the needs of their labour markets since such a policy may raise economic growth and social welfare. Host countries could reduce the supply of potential migrants by liberalising trade with sending countries. With the increased integration of EU labour markets, natural immigration laws have only limited effects.

Foreign workers should be permitted to perform seasonal work because, in the peak season, the additional supply of workers compensates for the shortage of labour without reducing domestic employment opportunities. Using simpler and more flexible rules, particularly in certain sectors, a considerable proportion of illegal foreign labour could be channelled into legal forms of work.

As regards policy on illegal migration, there have been some conflicts between the members of the EU. The experience of other regions and countries, including the USA, has already shown, however, that, as regards efficient protection against the inflow of illegal migrants, much room for manoeuvre remains in the policy-making of individual countries.

Until recently, migration policies in the EU were regarded mostly as domestic matters for the individual country. The debate on labour force mobility was encompassed within the elaborated European employment strategy. Over the last few years, however, the EU has conceded this rule and has begun to elaborate a framework for a common migration policy concerning the integration of immigrants (Box 2). 


\section{Box 2. EU efforts to build up a common migration policy}

The beginning of the working out of a common migration policy dated from the end of 2004 on the basis of the so-called Hague Programme, when the EU approved its 'Common Principles of Policy for Migrants' Integration'. In January of the next year, the EU introduced as a first common measure the so-called 'Green Book' for the management of economic migration. In December 2005, EU countries accepted the Policy Plan for the Management of Legal Migration, which should come into force in 2009. The basic directions of this policy are as follows:

a) immigrants' stable integration in labour markets, ensuring that they have access to education and employment services

b) the decline of undeclared employment and a reduction in the size of the informal economy

c) an estimate of real labour market demand within EU countries, and the role of immigrants, taking into account increased competition between host countries.

Thus, agreements on common migration rules have, step-by-step, been achieved. A specific directive focuses on seasonal migration (mainly in agriculture, construction and tourism). At the same time, the EU has accepted the 'Global Approach to Migration', mainly concerning policies related to the eastern, south-eastern and Mediterranean EU neighbours. Subsequent to July 2004, the EC has presented three annual reports. In 2008, it suggested a Common Framework Directive defining the basic rights of immigrants employed in EU countries as well as a directive concerning conditions for the immigration of highly-skilled specialists. The key term in these documents is employment, including non-discrimination and equal opportunities for migrants in terms of social cohesion, social support and access to education and training.

In September 2008, a new document was introduced - the European Refugees Pact. This is not a legal act but a codex for the $27 \mathrm{EU}$ countries, focusing mostly on individual cases rather than on mass migration. The main priorities are:

1. harmonising regulations for legal migration within the EU, giving priority to family migration combined with labour migration

2. struggling against illegal migration

3. strengthening the border controls of the EU

4. harmonising regulations concerning refugees

5. the north-south partnership.

The document is reliant on the influence of third (non-European) countries to reduce migration from their areas - Morocco, Lebanon, Ukraine.

Despite working on a common migration policy, we should be aware that individual countries are not much interested in co-operation. This is one of the reasons why a successful migration policy has not been developed. For this purpose, inter-governmental links must be strengthened. Future migration policy should have the quality of being selected by individual countries as promising, not simply tolerated just because it has already been accepted.

Source: http://ec.europa.eu

\section{Concluding remarks}

The increasing mobility of the population out of restrictive national borders is a natural consequence of the strengthening globalisation processes, in particular European integration and the free movement of capital and goods. More and more labour markets function like communication vessels and this should increasingly be taken into consideration when implementing regulatory policies on employment and migration.

Migration from central and eastern Europe to western Europe is on the EU agenda, and will continue to be so for the next few years: this is not just a mopping-up operation. How much of this will be efficient for the whole European labour market and development? On the basis of well-studied problems, the EU has to develop regulations and an institutional structure to be able to deal with the real situation. 
New member countries are likely to experience an outflow of skilled labour to the labour markets of 'old' EU countries, unless an economic catching-up with the economies of western countries occurs more quickly than expected.

Due to the lack of an immigration policy up to now in central and eastern European countries on the one hand, and to the increasing importance of this issue for these countries on the other, and as some of them form an external border of the EU, the main points concerning state policy still lie ahead.

The general question is: could the EU organise migration processes in a way to achieve favourable results for all EU countries concerning human capital and economic development? Yes. This is a difficult, but not impossible, policy.

\section{References}

Bems, R and P Schellekens (2008) Macroeconomics of Migration in New Member States International Monetary Fund, European Department: IMF Working Paper $\mathrm{WP} / 08 / 264$.

Borjas, G. J (1993) 'The Impact of Immigrants on Employment Opportunities of Natives' in: OECD: The Changing Course of International Migration, Organization for Economic Cooperation and Development: Paris.

Coppel, J, J-C Dumont and I. Visco (2001) Trends in Immigration and Economic Consequences Organisation for Economic Co-operation and Development, Economic Department Working Paper No. 284.

Daveri, F and R. Faini (1999) 'Risk and Migration' in: G. B. Navaretti, R. Faini and G. Zanalda (Eds.) Labour Markets, Poverty and Development Clarendon Press: Oxford.

Fóti, K (2007) 'Migration: Challenges and Opprtunities in Central and Eastern Europe with Special Regard to Hungary (Some possible economic impacts)' in: The Role of Human Capital in International Competitiveness. Transatlantic Comparison of Experience with Migration in the US and the EU Proceedings of international conference, 26 January 2007, Sofia (Bulgaria): 49-66.

Krasteva, A (Ed.) (2005) Immigration in Bulgaria International Centre for Minority Studies and Intercultural Relations: Sofia.

Inotai, A (2008) 'Impacts of Migration on the Economic Development of Sending Countries' in: Facing Challenges: Selected Key Issues of Economic Transformation and European Cooperation Proceedings of the Hungarian-Bulgarian Bilateral Workshop, 16 September 2005, Institute for World Economics and Hungarian Academy of Sciences, Budapest: 153-183.

Markova, E (2004) 'Legal Status and Migrant Economic Performance. The Case of Bulgarians in Spain and Greece' paper presented at the conference To Be A European. Bulgaria and Europe in Europe: Past, Present and Future University College London, 5 March 2004.

Rangelova, R and K. Vladimirova (2005) 'La nouvelle migration de Bulgarie. Strategies des acteurs dans le contexte de l'integration europeenne' in M. Alaluf and E. 
Krzeslo (Eds.) Protection sociale et emploi. Gegards croises sur la mondialisation en Europe at en Chine Editions de L'Universite de Bruxelles: 201-223.

Rangelova, R (2006) 'New Bulgaria's Emigration: Scale, Socio-demographic Profile, Economic Consequences' in: Facing Challenges: Selected Key Issues of Economic Transformation and European Cooperation Proceedings of the Hungarian-Bulgarian Bilateral Workshop, 16 September 2005, Institute for World Economics and Hungarian Academy of Sciences, Budapest: 50-73.

Rangelova, R (2008) 'Immigrant Integration into the Bulgarian Labour Market: Policy Implications' in: The Implication of EU Membership on Immigration Trends and Immigrant Integration Policies for the Bulgarian Labour Market Economic Policy Institute: Sofia, pp. 133-152.

United Nations (2000) Replacement Migration: Is it a Solution to Declining and Ageing Populations? Population Division, Department of Economics and Social Affairs: New York.

Vass, A (2007) 'Romanian Brain-Drain between Risk and Opportunity, Case Study: Students Mobility' in: The Role of Human Capital in International Competitiveness. Transatlantic Comparison of Experience with Migration in the US and the $E U$ Proceedings of international conference, 26 January 2007, Sofia (Bulgaria): 125-133. 